\title{
Hidradenitis Suppurativa Accompanying Crohn's Disease with Multifocal Abscess
}

\section{Multifokal Abse ile Seyreden Crohn Hastalığı ve Hidradenitis Süpürativa birlikteliği}

\author{
Muhammed Alpaslan, Ilyas Dundar, Fatma Durmaz, Harun Arslan, Abdussamet Batur
}

Yuzuncu Yil University Dursun Odabas Medical Center Department of Radiology, Van, Turkey

\begin{abstract}
To present an old patient with Crohn's disease and hidradenitis suppurativa presented with multifocal abscesses.

An 81-year-old female presented with complaints of weight loss, cough, and multiple painful swellings with foul-smelling pus discharge in the groin area. Computed tomography demonstrated multifocal entire the whole gastrointestinal tract.

It is of great importance to be aware of this association and the entire gastrointestinal tract should be investigated carefully, because a lack of awareness may lead to insufficient treatment.
\end{abstract}

Key Words: Crohn's disease, hidradenitis suppurativa, multifocal abscesses

\section{Introduction}

Crohn's disease (CD) and hidradenitis suppurativa (HS) are chronic, recurrent inflammatory diseases of the epithelia. In $\mathrm{CD}$, the inflammation may involve any part of the gastrointestinal tract, and is characterized by discontinuous transmural, inflammatory lesions of the gut wall (1). HS is a skin disease caused by concomitant occlusion of the apocrin glands. It usually manifests by recurrent abscesses, nodules, and draining sinus tracts localized in the groin and axillae, with resultant scarring (2-4).

The occurrence of both CD and HS in the same individual has been reported in several case reports and studies (2). There are several similarities between CD and HS. Both are chronic

\section{ÖZET}

Multifokal absesi olan yaşlı bir hastada Crohn hastalığı ve hidradenitis süpürativa birlikteliği sunmayı amaçladık.

81 yaşında kadın hasta öksürük, kilo kaybı, kasık bölgesinde kötü kokulu cerahat akıntısı ve çok sayıda ağrılı şişlik şikayetleri ile başvurdu. Bilgisayarlı tomografide tüm gastrointestinal sistemde, subkutanöz alanda, mediastinal-hiler ve axiller bölgelerde multifokal abse odakları saptandı. Subkutanöz abse odağından alınan biyopsi sonucu hidradenitis süpürativa, kolonoskopide intestinal traktan alınan biyopsi sonucu Crohn hastalığ olarak geldi.

Crohn hastalığ 1 ve hidradenitis süpürativa birlikteliğinin farkında olmak ve yetersiz tedaviyi önlemek için gastrointestinal sistemin iyi araştırılması büyük önem taşımaktadır.

Anahtar Kelimeler: Crohn hastalığı, hidradenitis süpürativa, multifokal apseler

diseases of the epithelia, but the etiology of both diseases is largely unknown. Smoking has been identified as a risk factor, and both show clinical responses to antiTNF-alpha. Moreover, fistula formation accompanies both (5).

We present a case with comorbidity of these two diseases in an old woman with multifocal abscesses.

\section{Case Report}

An 81-year-old female presented with complaints of weight loss, cough, and multiple painful swellings with foul-smelling pus discharge in the groin area, for the two previous months. The patient subsequently experienced abscesses and 
fistulas bilaterally in the axillae. The laboratory values were normal, except for a C-reactive protein value of $79 \mathrm{mg} / \mathrm{l}$. Her medical history was unremarkable. Investigations were carried out to look for any evidence of tuberculosis, hidradenitis suppurativa, or malignancy. A tissue culture did not reveal acid-fast bacilli or any other bacterium, and a stain for acid-fast bacilli was negative. A punch-biopsy specimen of the skin revealed hidradenitis suppurativa. A colonoscopy than was performed, which revealed an area of fragile and ulcerated mucosa, $3 \mathrm{~cm}$ in diameter, within the ascending colon. A biopsy taken from the area revealed inflammation with a granulomas characteristic of Crohn's disease. Computed tomography, obtained to rule out the cough aetiology and the possibility of a tumour, demonstrated abscesses in each of the groinsparailiac spaces-right iliopsoas muscle (Figure 1a, b, c), the subcutaneous-pancreatic parenchymaretroperitoneal space (Figure 2a, b), the gastric wall-hepatic parenchyma-distal oesophagus (Figure $3 \mathrm{a}, \mathrm{b}$ ) and the hilar-mediastinal-axillary (Figure 4a, b, c).
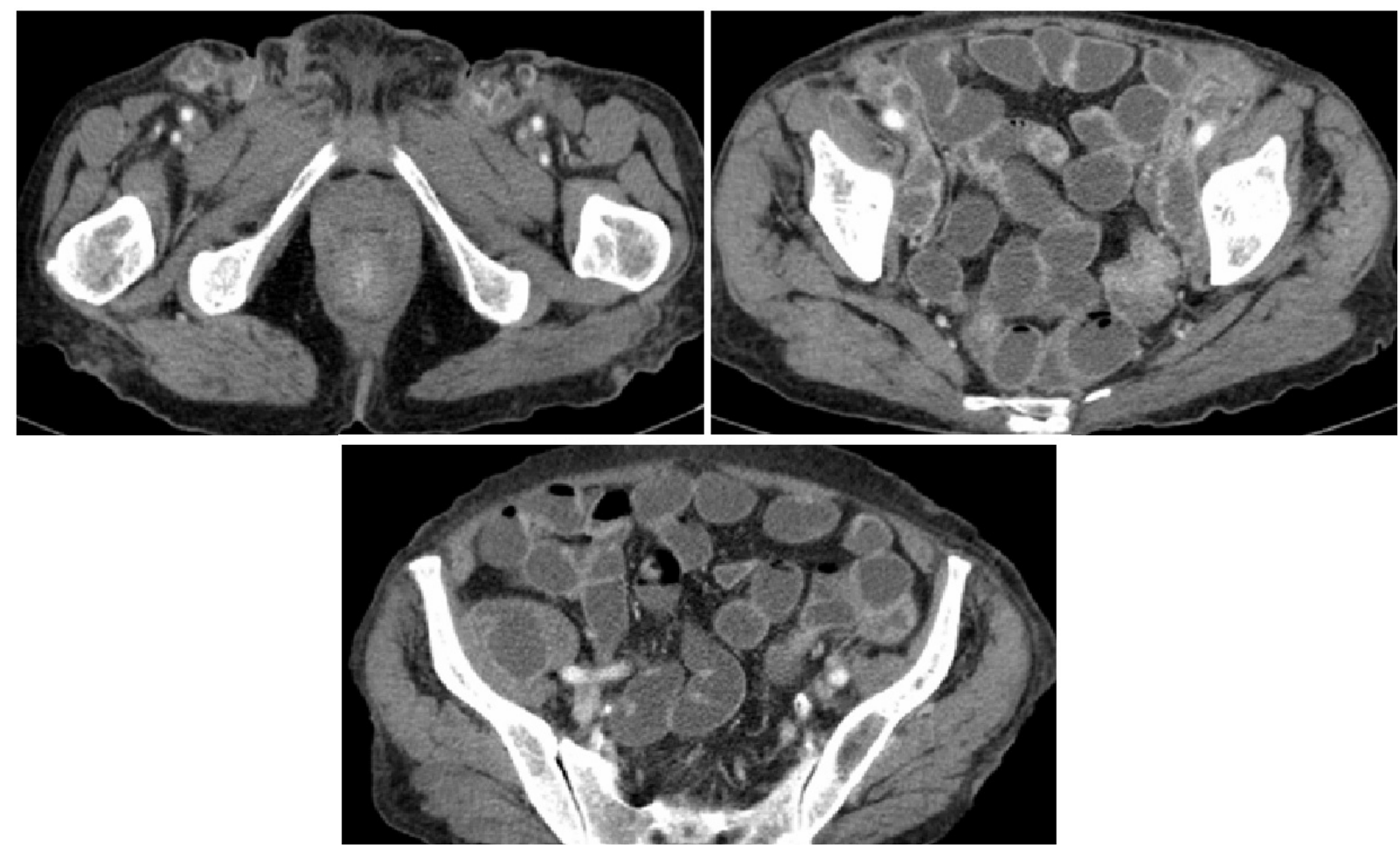

Figure 1. Computed tomography shows abscesses in each of the (a) groins- (b) parailiac spaces and (c) right iliopsoas muscle (arrows).
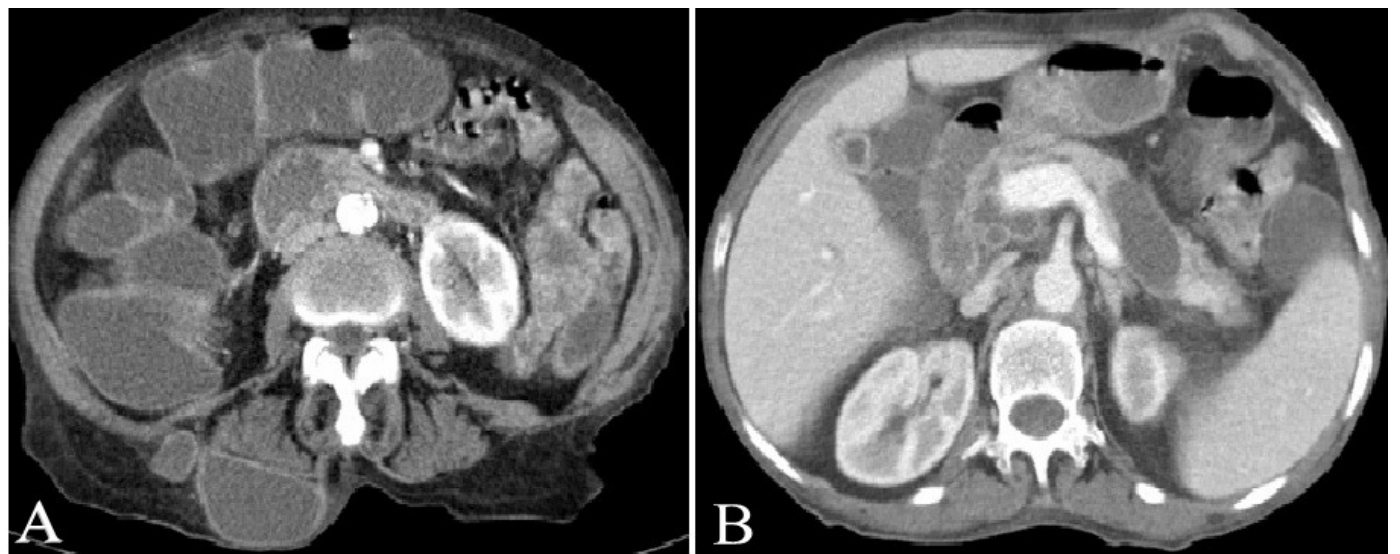

Figure 2. Computed tomography shows abscesses in each of the (a) subcutaneous, (b) pancreatic parenchyma (long arrows) and retroperitoneal space (short arrows). 

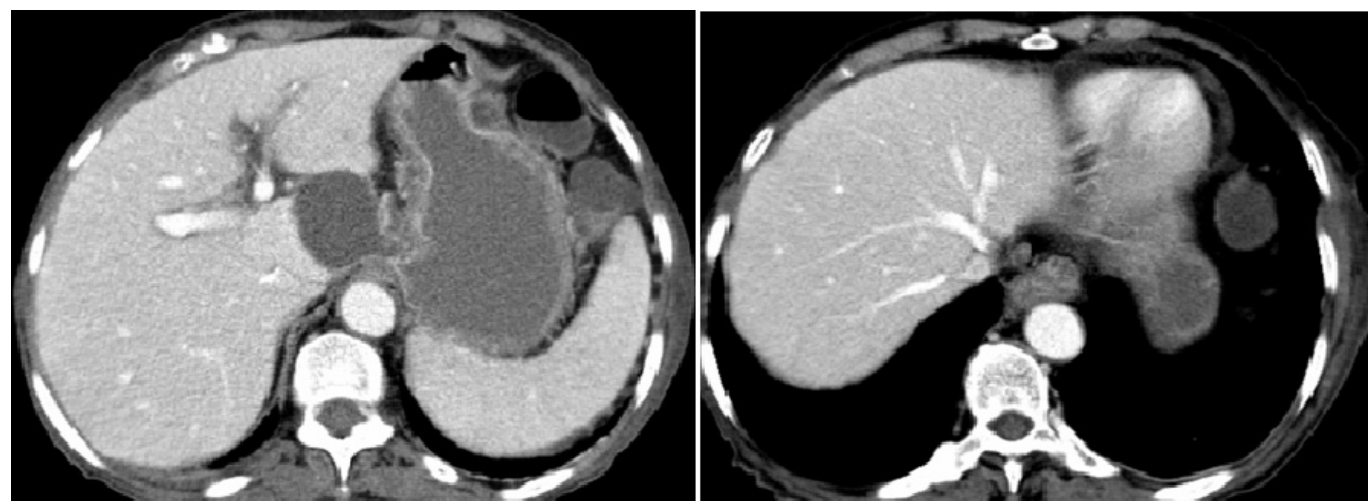

Figure 3. Computed tomography shows abscesses in each of the (a) gastric wall (short arrows), hepatic parenchyma (long arrow) and (b) distal oesophagus (arrows).
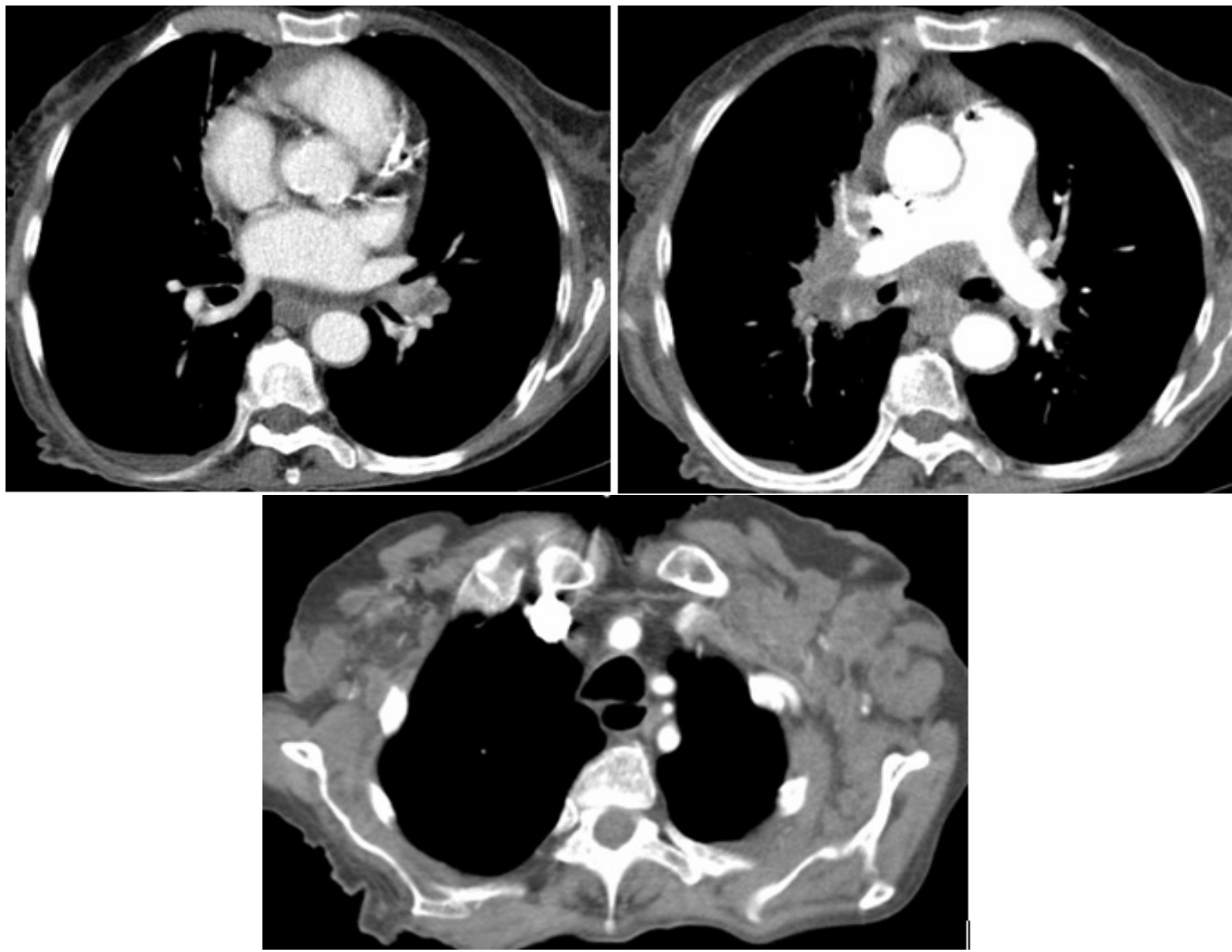

Figure 4. Computed tomography shows abscesses in each of the (a) hilar, (b) mediastinal and (c) axillary regions.

\section{Discussion}

Crohn's disease and hidradenitis suppurativa are chronic inflammatory conditions with epitheloid granulomas occurring in those with a constitutive tendency to form granuloma as part of an immunological abnormality (6). The association between them has been suggested in previous reports, but the precise meaning of this association remains unclear.

$\mathrm{CD}$ is an inflammatory bowel disease of unknown cause. Epidemiological studies suggest that the disease occurs in genetically susceptible individuals as a consequence of defects in mucosal barrier function and the disregulation of immune recognition of commercial gut flora (7). It is more 
frequent in women and smokers between 20 and 40 years old. HS consists of recurrent nodules, abscesses, or sinus tracts in apocrine gland-bearing areas, such as the axilla, groin, and perineum (8). The usual onset is at puberty, and the disease slows down by the mid-fourth decade. Females are more commonly affected (3). In women, HS may persist into the climacteric, but onset after menopause is rare (9). Obesity is associated with HS in more than $75 \%$ of cases, and it is considered to participate in the patophysiology of the disease (4).

The association between CD and HS was observed in a study of 61 patients; $24(39 \%)$ had lesions suggestive of $\mathrm{CD}$. In a major research study, $18(0.6 \%)$ out of $2,926 \mathrm{CD}$ patients presented with HS. The study also showed that $78 \%$ of those who had both diseases were smokers. It is interesting to note that both CD and HS occur primarily in areas rich in bacteria and have wholly different histopathology but share a common treatment (8).

As our case was different from the literature, there was no perianal fistula or abscesses and the patient was remarkably older (81 years old). In cases previously reported, Crohn's disease was mainly involved in the large bowel, but there were multifocal abscesses in relation to the entire gastrointestinal tract in our case.

The association of CD and HS may have an impact on treatment. It is of great importance to be aware of this association, because a lack of awareness may lead to insufficient treatment.

\section{References}

1. Yazdanyar S, Miller IM, Jemec GB. Hidradenitis suppurativa and Crohn's disease: two cases that support an association. Acta Dermatovenerol Alp Pannonica Adriat 2010; 19(3): 23-25.

2. Fimmel S, Zouboulis CC. Comorbidities of hidradenitis suppurativa (acne inversa). Dermatoendocrinol 2010; 2(1): 9-16.

3. Peters NJ, Kapoor R. Gluteal and perianal hidradenitis suppurativa associated with tuberulosis. Indian J Surg 2012; 74(2): 194-195.

4. Dessinioti C, Katsambas A, Antoniou C. Hidradenitis suppurativa (acne inversa) as a systemic disease. Clinics in Dermatology 2014; 32(39): 397-408.

5. Van der zee HH, Van der Woude CJ, Florencia EF, Prens EP. Hidradenitis suppurativa and inflammatory bowel disease: are they associated? Results of a pilot study. British Journal of Dermatology 2010; 162(1): 195-197.

6. Roy MK, Appleton MAC, Delicata RJ, Sharma AK, Williams GT, Carey PD. Probable association between hidradenitis suppurativa and Crohn's disease: significance of epithelioid granuloma. British journal of surgery 1997; 84(3): 375-376.

7. Scheinfeld N. Diseases associated with hidranitis suppurativa: part 2 of a series on hidradenitis. Dermatology online journal 2013; 19(6): 18558.

8. dos Santos CH, Netto PO, Kawaguchi KY, Parreira Alves JA, de Alencar Souza VP, Reverdito S. Association and management of Crohn's disease plus hidradenitis suppurativa. Inflamm Bowel Dis 2012; 18(4): 801-802.

9. Slade DEM, Powell BW, Mortimer PS. Hidradenitis suppurativa: pathogenesis and management. The British Association of Plastic Surgeons 2003; 56(5): 451-461. 